\title{
Construction and Characteristics of Experimental Prototypes of Ureteral Stents on the Basis of Resorbable Polyhydroxyalkanoates
}

\author{
Anatoly N. Boyandin*a,b, \\ Victoria V. Usenko ${ }^{b}$ and Mirgen P. Myltygashev \\ ${ }^{a}$ Institute of Biophysics $S B R A S$ \\ FRC "Krasnoyarsk Science Center SB RAS" \\ 50/50 Akademgorodok, Krasnoyarsk, 660036, Russia \\ ${ }^{b}$ Siberian Federal University \\ 79 Svobodny, Krasnoyarsk, 660041, Russia \\ ${ }^{c}$ V.F. Voino-Yasenetsky Krasnoyarsk State Medical University \\ 1 Partizan Zheleznyak Str., Krasnoyarsk, 660022, Russia
}

Received 26.02.2018, received in revised form 11.04.2018, accepted 21.05.2018

Resorbable polyhydroxyalkanoates (PHAs) have been studied for the first time as a biomaterial for production of ureteral stents. For manufacturing of stents, the solutions of polyesters in chloroform were poured into silicone tubes. In the static version of the method, the tube was clamped at the lower end to prevent leakage of the solution and fixed vertically until the solvent completely evaporated. In the dynamic version, the tube was regularly turned over, both ends being open, until the evaporation of the solvent. A polyester tube was formed along the inner walls of the silicone tube, which was then mechanically removed from the matrix tube. Based on the physical-chemical properties of PHA of various chemical compositions and the rheological properties of polymer solutions, the applicability of the poly (3-hydroxybutyrate-co-4-hydroxybutyrate [P(3HB/4HB)] copolymer and a blend of the poly (3-hydroxybutyrate) homopolymer with polycaprolactone for stent preparation was shown. The physical and mechanical characteristics of the experimental samples from $10 \%$ solutions of $\mathrm{P}(3 \mathrm{HB} / 4 \mathrm{HB})(10 \mathrm{~mol} . \% 4 \mathrm{HB})$ and $\mathrm{P}(3 \mathrm{HB}) / \mathrm{PCL}(25 / 75)$, in terms of mechanical strength (Young's modulus and stress at break), were close to those of a commercial polyurethane stent. It was shown that there was no hydrolysis of the samples in phosphate buffer at physiological pH values. The exposure of stents in a nephrostomy with urine flow showed a smaller degree of their incrustation by urinary salts and colonization by microorganisms in comparison with control stents made of polyurethane. Thus, a technique was developed for the production of polymer tubes by evaporation from a solution; a series of tubes with dimensional characteristics suitable for use as ureteral stents was obtained.

(C) Siberian Federal University. All rights reserved

* Corresponding author E-mail address: araneus@mail.ru 
Keywords: polyhydroxyalkanoates, biopolymers, ureteral stents, casting solution.

Citation: Boyandin A.N., Usenko V.V., Myltygashev M.P. Construction and characteristics of experimental prototypes of ureteral stents on the basis of resorbable polyhydroxyalkanoates. J. Sib. Fed. Univ. Biol., 2018, 11(2), 138-145. DOI: 10.17516/19971389-0056.

\title{
Конструирование и характеристики \\ экспериментальных образцов урологических стентов \\ на основе резорбируемых полигидроксиалканоатов
}

\author{
А.Н. Бояндин ${ }^{\text {a, }}$, В.В. Усенко \\ ${ }^{a}$ Институт биофизики СО РАН \\ ФИЦ «Красноярский научный иентр СО РАН» \\ Россия, 660036, Красноярск, Академгородок, 50/50 \\ ${ }^{6}$ Сибирский федеральный университет \\ Россия, 660041, Красноярск, пр. Свободный, 79 \\ ${ }^{8}$ Красноярский государственный медицинский университет \\ им. проф. Войно-Ясенецикого \\ Россия, 660022, Красноярск, ул. Партизана Железняка, 1
}

Впервые исследованы резорбируемые полигидроксиалканоаты (ПГА) в качестве биоматериала для изготовления урологических стентов. Для изготовления стентов в силиконовые трубки помещались растворы полиэфиров в хлороформе. В статическом варианте метода трубку зажимали на нижнем конце для предотвращения вытекания раствора и фиксировали вертикально до полного испарения растворителя. В динамическом варианте трубку регулярно переворачивали, оставляя оба конца открытыми, также до испарения растворителя. При этом вдоль внутренних стенок силиконовой трубки формировалась полиэфирная трубка, которая затем механически удалялась из трубки-матрицы. На основе изученных физико-химических свойств ПГА различного химического состава и реологических свойств полимерных растворов показана применимость для изготовления стентов сополимера поли-3-гидроксибутирата-4-гидроксибутирата [П(ЗГБ/4ГБ)] и смеси гомополимера поли-3-гидроксибутирата с поликапролактоном. Физико-механические характеристики экспериментальных образиов из 10\%-х растворов П(ЗГБ/4ГБ) (10 мол. \% 4ГБ) и П(ЗГБ)/ПКЛ (25/75) по показателям механической прочности (модуль Юнга и напряжение при разрыве) близки таковым у коммерческого стента из полиуретана. Показано отсутствие гидролиза образиов в фосфатном буфере при физиологических значениях рН. При экспонировании стентов в нефростоме с током мочи отмечена меньшая степень их инкрустации мочевыми солями и колонизации микроорганизмами по сравнению с контрольными стентами из полиуретана. Таким образом, разработана методика получения полимерных трубок методом испарения из раствора; получена серия трубок с размерными характеристиками, пригодными для применения в качестве урологических стентов. 
Ключевые слова: полигидроксиалканоаты, биополимеры, уретеральные стенты, испарение из раствора.

\section{Introduction}

The increasing use of minimally invasive procedures in recent years has made the placement of drainage stents as the normal practice in reconstructive surgery. The number of surgeries performed in the patients with the microcirculatory dysfunction of the cardiovascular system, diabetic angiopathy, and diseases involving the hepato-pancreato-biliary system and the upper urinary tract is growing steadily. However, the percentage of complications remains high, calling for improving the stents and systems employed to place and remove them, on the one hand, and using new materials, on the other.

Materials used for the production of ureteral stents should be characterized by high biocompatibility and must not cause negative reactions from the tissues at the implantation site. Stents should be durable and at the same time have sufficient elasticity. The latter is not always achievable when processing biopolyethers by melt extrusion, which requires finding other ways of obtaining materials in the form of tubes. A new direction of increasing the functionality of ureteral stents is the involvement of resorbable materials (polylactides, polyglycolides, polyurethanes) (Laube et al., 2007; Lock et al., 2012). The accumulated results of experimental and clinical studies of resorbable stents prove their prospective viability, but also adverse effects occur including migration and rapid loss of strength, expressed salt incrustation and microbial film formation (Barros et al., 2015; Chew \& Lange, 2009; Brotherhood et al., 2014), which actualizes research aimed at finding new materials for design of ureteral stents.

Polyhydroxyalkanoates (PHAs) of microbial synthesis are a family of biocompatible and biodegradable polyesters of various chemical structures with different basic properties, from highly crystalline thermoplastics to structural elastomers, which makes themimportantmaterials for medicine (Volova, 2004). Biodegradable poly-e-caprolactone is also considered to be a promising material for medical use, especially for manufacturing of various endoprostheses, carriers for cells, matrices for deposition of medicinal and biologically active substances, etc. (Abedalwafa et al., 2013).

The aim of the work was the construction by evaporation from solution and the study of polymer stents based on biodegradable polyesters.

\section{Materials and methods}

For production of stents, polyhydroxyalkanoate (PHA) samples of various compositions were used: homopolymer of poly-3-hydroxybutyrate ( $\mathrm{P}(3 \mathrm{HB})$, weightaverage molecular weight $\mathrm{M}_{\mathrm{W}}$ is $1220 \mathrm{kDa}$, and polydispersity $\mathrm{D}$ is 1.60 ) and two types of copolymers - poly-3-hydroxybutyrate-co3-hydroxyvalerate $(\mathrm{P}(3 \mathrm{HB} / 3 \mathrm{HV}), \quad 7.5 \mathrm{~mol} \%$ $\left.3 \mathrm{HV}, \mathrm{M}_{\mathrm{W}}=701 \mathrm{kDa}, Ð=3.27\right)$ and poly3-hydroxybutyrate-co-4-hydroxybutyrate $\left(\mathrm{P}(3 \mathrm{HB} / 4 \mathrm{HB}), 10 \mathrm{~mol} \% 4 \mathrm{HB}, \mathrm{M}_{\mathrm{W}}=569 \mathrm{kDa}\right.$, $Ð=5.12$ ). Bacterial PHAs were obtained by microbial biosynthesis using the strain Cupriavidus eutrophus B-10646 in various cultivation regimes, isolated and purified by reprecipitation in the

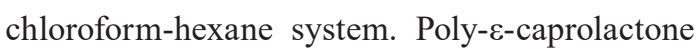
$\left(\mathrm{M}_{\mathrm{W}}=169 \mathrm{kDa}, \mathrm{D}=1.86\right)$ was purchased from Sigma-Aldrich. The rest of the reagents were purchased at a purity level of "analytical reagent grade" or higher at different manufacturers.

Stents were obtained by the technology of solvent evaporation from polymer solutions. We 
used silicon tubes into which chloroform solutions of polymers of various concentrations were poured and kept at room temperature in a dustfree box until the solvent completely evaporated. Polymer stents were obtained by two methods. In the first, static version, a hollow silicon tube with a clamp at the lower end to prevent leakage of the solution was vertically fixed in a holder, filled with a polymer solution and left in such a state until the solvent completely evaporated. In the dynamic mode, both ends of the 10-30-cmlong silicone tubes were left open, and the tubes were regularly turned over to prevent the solution from flowing out until the solvent completely evaporated.

To evaluate physical/mechanical parameters of the experimental tubes, ultimate tensile strength $(\mathrm{Pa})$, Young's modulus $(\mathrm{Pa})$, and elongation at break (\%) were determined using an Instron 5565,5 KN electromechanical testing machine (UK). The initial length of each sample was $5 \mathrm{~cm}$. To investigate stability of the stents in liquid media, they were incubated in phosphate buffered saline at $\mathrm{pH}$ varied between 4.5 and 7.8 and in urine of healthy humans. The clinically used stents of the same size were the control (“Unicorn Med”, Medical Instrument Co., Ltd., China).

\section{Results and discussion}

To construct ureteral stents, the technology of casting polymer solutions with subsequent evaporation of the solvent was used - "solvent evaporation" (Fig. 1). During the evaporation of the solvent, the ability of PHAs to form hollow polymer tubes as prototypes of stents was revealed.

For this method of production of polymer items, one of the determining parameters of the process is the properties of the polymer solution, in particular its dynamic viscosity. Polymer solutions were used based on the previously obtained results with respect to the dependence of the rheological properties of solutions on the type of solvent, the density of the solution, and the physical and chemical properties of PHAs (Goncharov \& Sukovatyi, 2016). In one of the previous studies, polymer solutions of various concentrations were formed using chloroform as a solvent. At room temperature $\left(20-25^{\circ} \mathrm{C}\right)$, the highest values of intrinsic viscosity were registered for solutions of $\mathrm{P}(3 \mathrm{HB}), 1162 \mathrm{cP}$, for a $5 \%$ solution. Copolymers were characterized by a significant decrease in the values of the index. Thus, for $5 \%$ solution of $\mathrm{P}(3 \mathrm{HB} / 3 \mathrm{HV})$ with $3 \mathrm{HV}$ monomer mass fraction of $9.9 \%$, a more than five-fold decrease in the investigated parameter to $258 \mathrm{cP}$ was recorded. The lowest intrinsic viscosity values were recorded for solutions of the copolymer $\mathrm{P}(3 \mathrm{HB} / 4 \mathrm{HB})$ - at a level of $19 \mathrm{cP}$ in a $5 \%$ solution of the copolymer with $4 \mathrm{HB}$ monomer mass fraction of $13.4 \mathrm{~mol} \%$. Thus, the studied solutions of PHAs should be arranged in the following order, in terms of decreasing

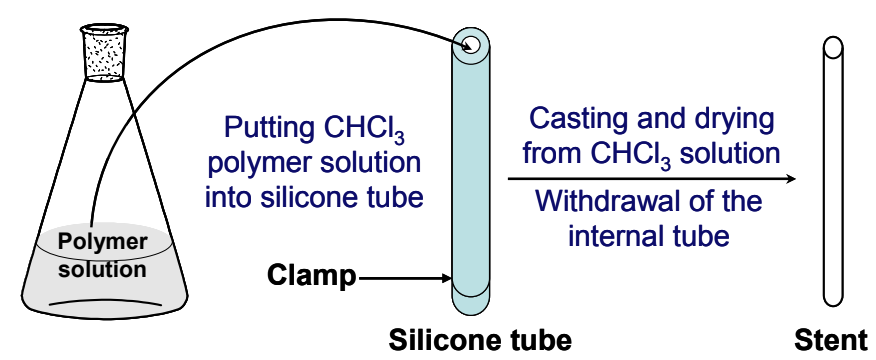

Fig. 1. Scheme of obtaining samples of ureteral stents 
dynamic viscosity value: $\mathrm{P}(3 \mathrm{HB})-\mathrm{P}(3 \mathrm{HB} / 3 \mathrm{HV})-$ $\mathrm{P}(3 \mathrm{HB} / 4 \mathrm{HB})$.

In the static mode of solvent evaporation, it was not possible to obtain tubes with an uniform wall thickness along the entire length.
At the upper measurement points (approximately $10 \mathrm{~cm}$ ), using a matrix with an internal diameter of $3 \mathrm{~mm}$ (Fig. 2a), the thickness of the walls was minimal, amounting to $0.014-0.016 \mathrm{~mm}$ in tubes obtained from solutions of $\mathrm{P}(3 \mathrm{HB})$ and $0.010-$
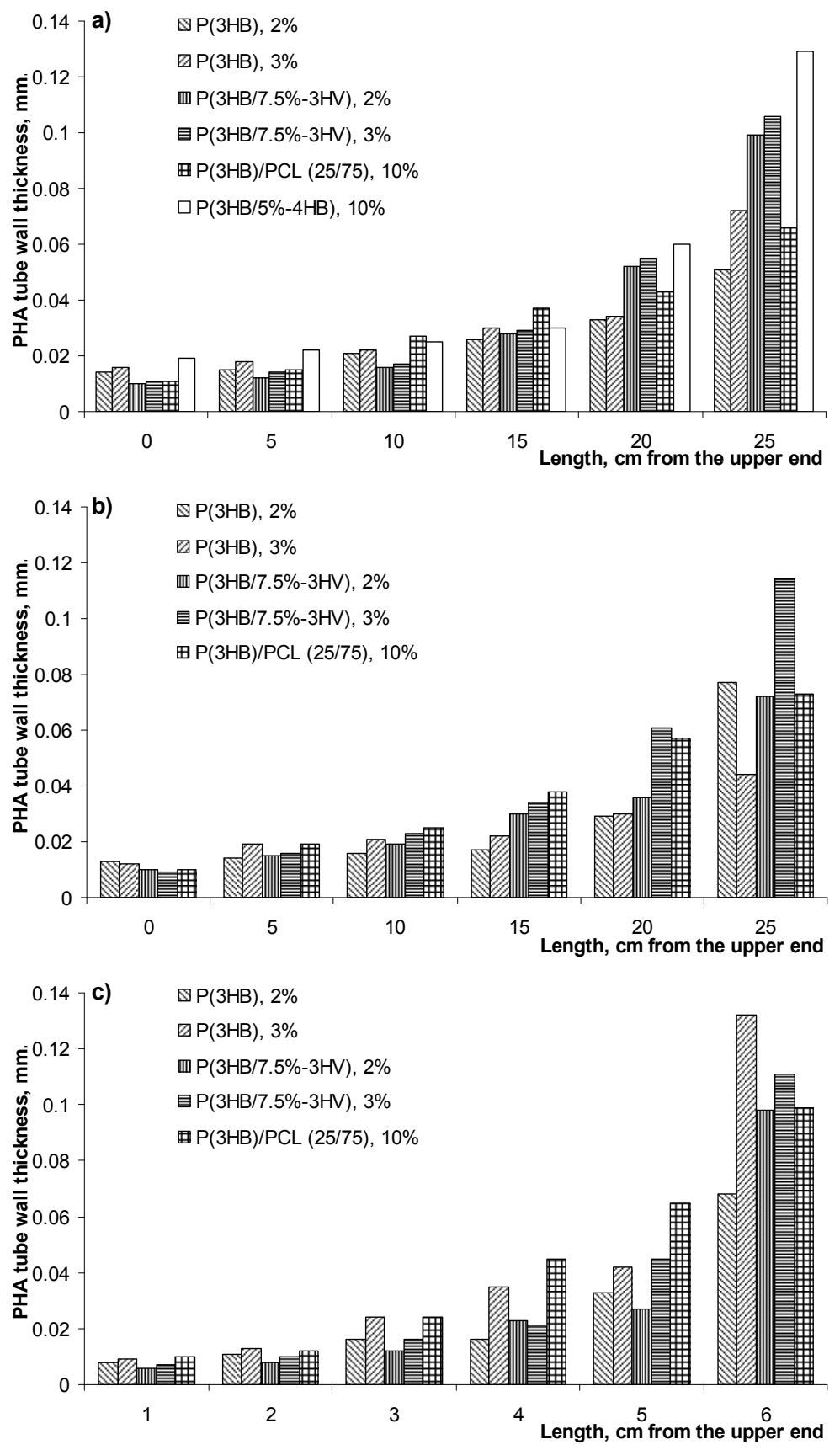

Fig. 2. Changes in the thickness of the walls of polymer stents depending on the composition and concentration of the polymer solution and the diameter of the matrix tube: a) $3 \mathrm{~mm}$; b) $4 \mathrm{~mm}$; c) $6 \mathrm{~mm}$ 
$0.014 \mathrm{~mm}$ for tubes obtained from solutions of the copolymer $\mathrm{P}(3 \mathrm{HB} / 3 \mathrm{HV})$. Thus, when $30-\mathrm{cm}$-long tubes were used, starting from about $15 \mathrm{~cm}$ from the top of the tube, the walls became thicker; the thickness of the walls gradually increased as it moved away from the top of the tube to its lower part, apparently as a result of an increase in the concentration of the polymer solution flowing down inside the silicone matrix tube under gravity. At the last measurement points (at a level of $25-20 \mathrm{~cm}$ ), the wall thickness was 0.051 and $0.072 \mathrm{~mm}$ when using 2 and $3 \%$ $\mathrm{P}(3 \mathrm{HB})$ solutions and 0.099 and $0.106 \mathrm{~mm}$ when using similar solutions of $\mathrm{P}(3 \mathrm{HB} / 3 \mathrm{HV})$. In the lower part of the tube, a polymer cluster without a lumen was formed. Thus, the thickness of the walls varied along the entire tube, which is unacceptable for stenting. This method was not suitable for obtaining stents with satisfactory and stable geometric parameters. When using silicone template tubes with diameters of 4 and $6 \mathrm{~mm}$ (Fig. $2 \mathrm{~b}$ and 2c, respectively) and P(3HB) and $\mathrm{P}(3 \mathrm{HB} / 3 \mathrm{HV})$ solutions, an increase in the diameter of the template made the stent walls even thinner.

The next step was to study the dynamic method of obtaining tubes, involving flipping upside down, from solutions of the copolymer $\mathrm{P}(3 \mathrm{HB} / 4 \mathrm{HB})$ with 4-hydroxybutyrate monomer content of 10 and $30 \mathrm{~mol} \%$. Copolymers containing $4 \mathrm{HB}$ monomers have a significantly reduced degree of crystallinity and rheological characteristics, which differ from the solutions of highly crystalline $\mathrm{P}(3 \mathrm{HB})$ and $\mathrm{P}(3 \mathrm{HB} / 3 \mathrm{HV})$, whose dynamic viscosity values are orders of magnitude higher.

Significantly reduced values of dynamic viscosity of $\mathrm{P}(3 \mathrm{HB} / 4 \mathrm{HB})$ copolymer solutions made it possible to use more concentrated solutions, up to $5-10 \%$, during the development of the technology for obtaining stents. Stents obtained as a result of such a turn over, when using a 30-cm-long silicone matrix with an inner diameter of $3 \mathrm{~mm}$, had a uniform wall thickness of $0.010-0.015 \mathrm{~mm}$ with $5 \%$ solutions and $0.024-$ $0.028 \mathrm{~mm}$ with $10 \%$ polymer solutions in the middle third $(10 \mathrm{~cm})$ of the tubes. A similar result was obtained using composite solutions formed by $\mathrm{P}(3 \mathrm{HB})$ and polycaprolactone (PCL).

The mixed solutions of $\mathrm{P}(3 \mathrm{HB})$ and $\mathrm{PCL}$ with a different ratio of components were studied for obtaining samples of ureteral stents. Initially, mixtures of $\mathrm{P}(3 \mathrm{HB}) / \mathrm{PCL}$ with component mass ratios of $10 / 90$ and 25/75 were taken, of which $10 \%$ solutions were prepared. The best results were obtained using $10 \%$ solutions with the $\mathrm{P}(3 \mathrm{HB}) / \mathrm{PCL}$ ratio being $25 / 75$. With a component ratio of $10 / 90$, it was not possible to obtain a sufficiently smooth surface of the obtained stents, and therefore no further studies were performed with them. The use of $\mathrm{P}(3 \mathrm{HB} / 4 \mathrm{HB})$ and $\mathrm{P}(3 \mathrm{HB}) / \mathrm{PCL}$ in the given concentration for manufacturing of tubes by the technology of solution casting with subsequent evaporation of the solvent in the dynamic mode ensured acquisition of experimental samples of ureteral stents with geometric dimensions corresponding to those used in practice.

Tubular stents are subject to dynamic (radial, axial, etc.) loads during placement and when the patient moves. Therefore, friction properties of the materials used to construct stents and the produced stents need to be investigated. Measurements showed that mechanical strength (Young's modulus and flexural strength) of the tubes prepared from $10 \%$ solutions of $\mathrm{P}(3 \mathrm{HB} / 4 \mathrm{HB})$ and $\mathrm{P}(3 \mathrm{HB}) / \mathrm{PCL}$ solutions were similar to the corresponding parameters of commercial polyurethane stents (Table 1), although elasticity (elongation at break) in the case of the $\mathrm{P}(3 \mathrm{HB} / 4 \mathrm{HB})$ stents was considerably lower.

Ureteral stents are intended to be in contact with urine, which is a corrosive medium and affects them adversely. The effects produced 
Table 1. Physical/mechanical properties of the experimental stents from polymers of different compositions (averages of measurements of 5 samples and standard deviation)

\begin{tabular}{|l|c|c|c|c|}
\hline \multicolumn{1}{|c|}{ Polymer composition } & Diameter, mm & $\begin{array}{c}\text { Young's modulus, } \\
\mathrm{MPa}\end{array}$ & $\begin{array}{c}\text { Flexural strength, } \\
\mathrm{MPa}\end{array}$ & $\begin{array}{c}\text { Elongation } \\
\text { at break, } \%\end{array}$ \\
\hline Control (polyurethane) & 2.7 & $197.92 \pm 21.65$ & $16.00 \pm 1.00$ & $439.94 \pm 5.94$ \\
$\mathrm{P}(3 \mathrm{HB}$ ) (from 2\% solution) & 6.0 & $345.60 \pm 11.60$ & $9.00 \pm 3.40$ & $2.95 \pm 0.69$ \\
$\mathrm{P}(3 \mathrm{HB})$ (from 3\% solution) & 6.0 & $560.20 \pm 17.50$ & $5.90 \pm 2.02$ & $1.78 \pm 1.05$ \\
$\begin{array}{l}\mathrm{P}(3 \mathrm{HB} / 7.5 \text { mol.\% 3HV) } \\
\text { (from 3\% solution) }\end{array}$ & 6.0 & $192.50 \pm 15.40$ & $28.87 \pm 4.56$ & $2.45 \pm 0.45$ \\
$\begin{array}{l}\mathrm{P}(3 \mathrm{HB} / 10 \text { mol.\% 4HB) } \\
\text { (from 10\% solution) }\end{array}$ & 3.0 & $230.23 \pm 35.70$ & $9.38 \pm 0.50$ & $111.01 \pm 10.97$ \\
$\begin{array}{l}\mathrm{P}(3 \mathrm{HB}) / \mathrm{PCL}=25 / 75 \\
\text { (from 10\% solution) }\end{array}$ & 3.0 & $170.90 \pm 2.16$ & $11.18 \pm 1.36$ & $339.32 \pm 21.05$ \\
\hline
\end{tabular}

by urine include encrustation, erosion, destruction, and loss of mechanical properties of the implant. Incubation of the experimental tubes in buffer solutions at $\mathrm{pH}$ from 4.5 to 7.8 for 12 days did not cause any significant changes in the weight of the tubes and molecular weight properties (average molecular weight and polydispersity) of the polymers used to fabricate them. Mechanical properties did not change significantly either.

To estimate the resistance of experimental stents to the effects of urine, they were placed for 7 days into catheters maintaining unobstructed urine flow in the patients that had been surgically treated for urolithiasis. Less encrustation and lower colonization by microorganisms were observed in experimental stents than in polyurethane (control) stents.

\section{Conclusion}

A technique for obtaining polymer tubes by the method of evaporation from a solution was developed. The experimental tubes had size properties and mechanical characteristics appropriate for ureteral stents. Mechanical properties did not change significantly during incubation in buffer solutions at $\mathrm{pH}$ from 4.5 to 7.8 for 12 days. Encrustation and colonization by microorganisms after exposition in urine flow were lower in experimental stents than in control stents.

\section{Acknowledgements}

The study was supported by the State budget allocated to the fundamental research at the Russian Academy of Sciences (project No. AAAA-A17-117013050028-8).

\section{References}

Abedalwafa M., Wang F., Wang L., Li C. (2013) Biodegradable poly-epsilon-caprolactone (PCL) for tissue engineering applications: a review. Reviews on Advanced Materials Science, 34: 123-140

Barros A.A., Rita A., Duarte C., Pires R.A., Sampaio-Marques B., Ludovico P., Lima E., Mano J.F., Reis R.L. (2015) Bioresorbable ureteral stents from natural origin polymers. Journal of Biomedical Materials Research Part B: Applied Biomaterials, 103: 608-617

Brotherhood H., Lange D., Chew B.H. (2014) Advances in ureteral stents. Translational Andrology and Urology: Home, 3: 314-319

Chew B.H., Lange D. (2009) Ureteral stent symptoms and associated infections: a biomaterials perspective. Nature Reviews Urology, 6: 440-448 
Goncharov D.B., Sukovatyi A.G. (2016) Rheology of polyhydroxyalkanoate solutions. Journal of Siberian Federal University. Biology, 9: 190-197

Laube N., Kleinen L., Bradenahl J., Meissner A. (2007) Diamond-like carbon coatings on ureteral stents - a new strategy for decreasing the formation of crystalline bacterial biofilms? Journal of Urology, 177: 1923-1927

Lock J.Y., Draganov M., Whall A., Dhillon S., Upadhyayula S., Vullev V.I., Liu H. (2012) Antimicrobial properties of biodegradable magnesium for next generation ureteral stent applications. Conference Proceedings of the IEEE Engineering in Medicine and Biology Society, p. 1378-1381

Volova T.G. (2004) Polyhydroxyalkanoates - plastic materials of the $21^{\text {st }}$ century: production, properties, and application. New York, Nova Science Publishers, 282 p. 